\title{
Rachel Hennessy
}

\section{'The ability to see and the talent to speak': The emergent writer and questions of voice and authority}

\begin{abstract}
With the question of appropriation in fiction in debate - given prominence through the furore caused by Lionel Shriver's keynote speech at the Brisbane Writers Festival in October 2016 - the importance of discussing issues of voice and authority with emergent writers has become ever more apparent. Yet how should these ideas be discussed with student writers who are still coming to terms with craft notions such as point-of-view and narrative voice? What alternatives are available other than focusing on privilege and power, where students tend to retreat into their subjugated identities to justify their speaking positions? And when discussing 'the right' to tell other people's stories how can a recognition of fiction writing as a political act in itself move emergent writers away from the idea of 'making things up' towards a more engaged view of their practice? This paper will attempt to answer some of these questions via a mixture of voices itself, utilising the 'voice of experience' of the tertiary teacher as well as that of the practicing creative writer whose own work - a draft novel entitled 'The Master Class' - is concerned with fiction as, inevitably, an act of appropriation and utilities a narrative where fictional characters directly engage with the question of who owns a story.

Keywords: appropriation, authority, creative voice, identity
\end{abstract}

To begin to write a paper on the question of 'voice', I would like to begin with the question of the voice in the paper. Should I adopt the objective, pronounless, masculine voice which effaces the apprentice academic sitting at her desk? Do I choose a voice grounded in literary theory, the voice that, as Jane Tompkins identified, pretends 'that epistemology, or whatever you're writing about, has nothing to do with your life, that it's more exalted, more important, because it (supposedly) transcends the merely personal'? (Tompkins 2001: 2130-2131) Here, rather than actually being personal, this voice attempts to gain authority by inserting a quote from someone of more note than the author herself.

Or, if I step away from this voice and, as Stephen Muecke identifies in the field of fictocriticism, collapse "the "detached" and all-knowing subject into the text, so that his (or your) performance as writer includes dealing with a problem all contemporary writers must face: how the hell did I get here?' (Muecke 2002: 108) then what performing writer am 'I' and what 'here' have I got to? I have applied for Australia Council grants as an 'emerging', 'developing', 'developed' and 'established' writer, and felt the material repercussions of being accepted, and rejected, as such. If, indeed, the I who now addresses you has any kind of stable identity - in a post-post-modern world where everything I speak is but a 'tissue of quotations' (Barthes 2001: 1468) - then my position 
as 'professional writer' stems, in the university classroom, not from any absolute truth, no sense that I have 'arrived' anywhere, but from achievement only by comparison: I have published, my students (mostly) have not. The voice I then adopt, in both this paper and the classroom is one of Authority, with a capital 'A' because I am the Author, a designation which applies when the writer's words are published. I have two physical books to prove my status and I speak, apparently, with the voice of experience and knowledge.

Yet, there is another voice which wishes to insert itself: that of the practicing creative writer, the non-academic, who worries at the ideas to be explored in this paper in a different way. To allow her space, I have inserted quotations from my third novel, a work-in-progress entitled 'The Master Class', to sit inside/astride the text. This is an attempt to create what Ross Watkins and Nigel Krauth describe in 'Radicalising the scholarly paper: New forms for the traditional journal article' as a 'literal mosaic or constellation of ideas forming in front of us' (Watkins \& Krauth 2016). In their example, Watkins and Krauth weave their email correspondence regarding the article's creation into the article itself, generating layers of conversation around their argument. They propose many future options for the academic paper, to shape 'a new concept of intellectual production and connectivity', contending that creative writing is 'in the box seat for exploring and exploiting new, flexible and dynamic knowledge forms' (Watkins \& Krauth 2016).

By weaving a creative narrative - which is, itself, concerned with questions of representation and owning of story - into the academic theorising of voice, I hope to enter into this challenging of what form an academic article can take. This 'sandwich effect', as Hazel Smith has identified as one of the many creative-critical hybrid forms, 'facilitates the ability to enter a topic, or set of topics, from a multiplicity of angles' (Smith 2014: 337), though I do not pretend these creative sections were written in conjunction with the article. Rather, at the same time as teaching writing, I have been working on a novel project which has become 'infected' with these questions of pedagogy. In having these texts speak to one another, a dialogue between the 'writer who teaches' and the 'teacher who writes' (Cowan 2012) is enacted, these extracts serving as a different form of engagement with ideas about voice, authority and narrative responsibility.

\section{The book arrived yesterday.}

Jemima drove into town and picked it up from the post office, flashing her passport and giving one of her strained smiles. She was always there collecting parcels - contemporary novels ordered on the net-yet none of the staff remembered her, or pretended not to. They invariably searched for letters first, exchanging words she couldn't catch, gesturing impatiently towards the back when nothing was found in the small slots. She tended to sweat in these moments, displaying a sense of guilt for being foreign and ignorant, and the attendants never handed over her packages with much grace. More often than not, they were thrown onto the plastic-coated counter without a word, a seeming gesture of belligerence she tried not to take personally.

This time, she must have looked her worst. Heart hammering with the intensity of a meeting with a lover, as if this particular collection of words held the same possibilities as an encounter 
with a longed-for body. She felt so nervous, her hands actually shook. Tremors, for God's sake! Like some nineteenth century virgin heroine all overcome by the un-expected moment of fleshiness. How George would have sneered.

All a flutter, Jemima? How very bourgeois of you. It is only fiction, after all. Jezuuus! Don't you know how little it all means?

No, George, she didn't know how little it all means, or meant. She wasn't able to dismiss the moment, to make it a footnote, a tiny tremble in the timeline of her life. She wasn't able to make clear judgements back then and, even after fifteen years, even after so much time has passed and she should've reached some kind of enlightenment, some wisdom brought from ageing, the wrinkling round the eyes, the furrowing of the thoughtful brow, she's still isn't sure how to weave the story of her actionswhere to place her character in the narrative of that period or how to measure the level of importance assigned to her - or, most of all, how to separate what actually happened from the fiction she herself created. And, now, someone else has done it for her.

When I discuss the notion of voice in the creative writing classroom, I am speaking of something quite different than this debate around what form an academic paper should take, yet the voice in which I speak of 'voice' echoes through this conversation: what self am I presenting to the student? How do I claim Authority as a teacher and scholar? And, at the core of this paper, who am I to tell a student what voice they can or cannot speak in?

The creative writing workshop model under which I teach at the University of Melbourne remains strongly within what Paul Dawson identifies as the 'sublime', where the student is praised for 'the well-wrought line, the striking metaphor, the finely constructed scene, the authentic "voice" (Dawson 2007: 84). The sublime model, for the most part, arises from examinations of realistic writing, where the narrator is a created character, separate from the writer, though containing traces. It often relies on what Michelene Wandor has criticised as the fundamental conviction 'that the core source of fiction is always the self, the personal experience' (Wandor 2004: 118). The stated struggle for many student writers is to erase these traces: to, effectively, fictionalise the self and embody a voice which speaks its own unique style, a goal which is closely tied to the idea of individual genius. As Stephanie Vanderslice puts it:

It is a fact universally acknowledged (but hopefully not encouraged) by most teachers of creative writing that the heads of undergraduate or beginning writers virtually teem with the myths they've spent their whole lives absorbing about writers and writing via popular culture including: that writing is easy; that perfect first drafts spring from pens or keyboards fully formed; that writing itself is reserved for crazed, isolated, drugaddicted "geniuses". (Vanderslice 2011: 30)

While the notion of the drug-addicted 'genius' seems to have waned, the idea of connection with self as one of the primary sources of creativity remains strong in curriculum design. Learning outcomes are often articulated in terms 
that highlight the use of past and present experience. The University of Melbourne, for example, expects that students will have

had an opportunity to play with ideas, drawing on their experience and memory to draft and develop their own creative written works to a high standard. (University of Melbourne 2018)

Similarly, a creative writing unit at Deakin University

approaches literature and literary study as important pathways to unlocking our identities and understanding our lives, affirming the potential for transformation of the self that literary texts and study offer. (Deakin University 2018)

Dawson compares the 'sublime' model to that of the 'avant-garde aesthetic' which 'encourages and rewards formal experimentation, subversion and renovation of genre, dialogic engagement with non-literary discourses, intellectual curiosity, political awareness and social responsibility' (Dawson 2007: 84). Andrew Cowan, in 'A live event, a life event: The workshop that works', analyses various models, but claims 'it is a matter of emphasis' as to whether the workshop 'will fall on the deployment of a work's formal resources rather than any concerted scrutiny of what the work may reveal about politics or society' (Cowan 2012).

In my experience of workshopping over the last five years - primarily in undergraduate courses - the ongoing emphasis has been on writing as a search for textual cohesion, via examination of craft elements such as point-of-view, narrative voice and framing, with little room left for the examination of broader social issues or questions of representation. The shift I encountered, when I began to teach a postgraduate course called 'Theory for Writing' (renamed 'Thinking Writing: Theory and Creativity' this year), established at the University of Melbourne by Elizabeth MacFarlane in 2008 was, therefore, somewhat profound. Drawing attention to the dislocation between language and meaning, via the ideas of post-structuralism and post-modernism, tested many students whose exposure to literary theory had been minimal up until that point. In particular, the challenge posed by postmodernity's denial of fixed notions of self and identity seemed to be in direct contradiction to the tenets of craft-based realistic writing processes, such as 'write what you know' and 'find your voice':

not only is the bourgeois individual subject a thing of the past, it is also a myth; it never really existed in the first place; there have never been autonomous subjects of that type. Rather, this construct is merely a philosophical and cultural mystification which sought to persuade people that they "had" individual subjects and possessed this unique personal identity. (Jameson 2001: 1964)

In the two years of teaching the course, I have encountered students who find this notion threatening - particularly when writing has been intricately tied to their idea of self - and others who find it exciting. Theory either produces a longing to simply write down one's 'reality' - and, given realism is still the dominant force in the publishing industry, this remains a valid response - or it is seen as an opening to a greater awareness of the ways in which reality is constructed via language; the ways in which we can play with story-telling with self-consciousness and the meta-text; the opportunities to write back to the notion of individual style and to escape the pressure of excavating self. 
The place of critical theory in the creative writing workshop has been explored often (Sved 2005; Fraser 2008; Harris 2009; Ramey 2014; Quilford 2016) but it seems ever more apposite to consider it at a time when, as Enza Gandolfo asserts, we 'need to talk about identity politics and cultural appropriation and what it means to be a writer in Australia today' (Gandolfo 2016). While Jameson may have denied the 'bourgeois individual subject' a unique personal identity, the post-human body has been reinscribed with its markers: who we are in terms of race, class, gender, sexuality, able-ism and, in the Anthropocene Age, even as a species, has become an issue in literary representation, raising questions not only about our ability to voice story and narrative, but our right to.

Are there some of us who are just not born with the ability to be more than ordinary? They say ten percent of healthy people have delusions of grandeur. But when do the great know they are great? What are the ingredients for greatness? Can some of us never aspire to the heights because of the land in which we are born, because of the plain and dull nature of our upbringing? When does the point come, when we tip over from simply producing something into creation, when the finger of the muse touches our plodding and transforms them into a masterpiece? How much do we long for it? And how much are we prepared to sacrifice?

In September 2016, I took the debate raised by Lionel Shriver's keynote speech at the Brisbane Writers Festival about 'fiction and identity politics' into a classroom of third-year university creative writing students. As some of them were unaware of the incident, I provided them with Power-point slides, the first with a quote from Shriver:

However, are we fiction writers to seek "permission" to use a character from another race or culture, or to employ the vernacular of a group to which we don't belong? Do we set up a stand on the corner and approach passers-by with a clipboard, getting signatures that grant limited rights to employ an Indonesian character in Chapter Twelve, the way political volunteers get a candidate on the ballot? ... I am hopeful that the concept of "cultural appropriation" is a passing fad: people with different backgrounds rubbing up against each other and exchanging ideas and practices is self-evidently one of the most productive, fascinating aspects of modern urban life. But this latest and little absurd no-no is part of a larger climate of supersensitivity, giving rise to proliferating prohibitions supposedly in the interest of social justice that constrain fiction writers and prospectively makes our work impossible. (Shriver 2016b)

I then gave them this quote, including the title of the article:

\author{
As Lionel Shriver made light of identity, I had no choice but to \\ walk out on her, \\ by Yassmin Abdel-Magied:
}

It's not always OK if a white guy writes the story of a Nigerian woman because the actual Nigerian woman can't get published 
or reviewed to begin with. It's not always OK if a straight white woman writes the story of a queer Indigenous man, because when was the last time you heard a queer Indigenous man tell his own story?... Cultural appropriation is a "thing", because of our histories. The history of colonisation, where everything was taken from a people, the world over. Land, wealth, dignity ... and now identity is to be taken as well? In making light of the need to hold onto any vestige of identity, Shriver completely disregards not only history, but current reality. The reality is that those from marginalised groups, even today, do not get the luxury of defining their own place in a norm that is profoundly white, straight and, often, patriarchal. And in demanding that the right to identity should be given up, Shriver epitomised the kind of attitude that led to the normalisation of imperialist, colonial rule: "I want this, and therefore I shall take it”. (Abdel Magied 2016)

In the classroom, the divide between opinions was startlingly clear: on the one hand, those who advocated for writing whatever you wanted - art as imagination, without political intent and as the storehouse of empathy - and, on the other, those who recognised the power and privilege of their subject position and their belief in the validity of the question: 'Who has the right to write what story?' The fixed views of those on both sides led to what I later considered to be an un-productive debate, as students declared either their access to oppression - 'as a woman, I feel...' - or their indifference to such limitations: 'the whole point of fiction writing is to step into other people's shoes'.

The general responses to Shriver's speech and subsequent article in the New York Times - 'Will the Left Survive the Millennials?' (Shriver 2016a) - seem to reflect this basic divide and I do not plan to wade through the mountain of opinion pieces it provoked. What interests me, again, is what effect this calling into question of the role of self and identity has on the student writer and notions of voice and point of view. On the one hand, the post-post-modern denial of unique and authentic voice maintains that the multi-fractured subject has no access to a stable self, we exist in 'a realm of floating signifiers, random connections, improvisations, approximation, accidents, and "slippage" (Barry 2009: 124). On the other, identity is intrinsically linked to historical layers of oppression and the lived experience of the writer, their access to "truth" granted via unmediated personal knowledge of culture, race, sexuality and/or disability. Here, the apprentice may be encouraged towards exploring their Other-ed selffor example, a student reported to me how an instructor told her to write her characters 'more Asian' - or be steered away from attempting to represent anything but their known subject-hood. The more nuanced response to these two seemingly divergent stances may be to initiate a discussion around being responsible, in the dictionary definition of the word as 'able to answer for one's conduct and obligations' (Merriam-Webster 2018).

Jeanine Leane argues in 'Writing Other People's Stories' that:

to achieve empathy one must know those they are seeking to represent - and not just through limited and controlled observation, or through a state archive, or someone else's research. Rather they must know through social and cultural immersion. (Leane 2016: 43)

The technique of immersion is one which has been long adopted by writers of nonfiction and the use of this terminology in regards to fiction is telling. 
Henceforth, the argument goes, the fiction writer needs to saturate themselves in the experiences of the Other before they can write with any authenticity or authority. Yet how much immersion is enough to grant the writer a 'pass' into imaginative realisation? (And the use of the word 'pass' is not chosen without knowledge of what this term holds within it.) In contrast to Leane, Wandor proposes that:

What we write about has to be felt and therefore experienced, but it can be experienced in the imagination and needn't be necessarily lived experience. Leaving aside what might be meant by "felt" and "experienced", the notion that you must have "lived" what you put into fiction, not only harks back to the Romantic idea that the writer must suffer to be an artist, it assumes that the only "knowledge" a writing student needs is that of him/herself. (Wandor 2004: 117)

This issue of lived versus imagined experience is a pertinent one for student writers.

I wrote my first novel in an arrogant surge of self-belief ('I am a great and unique writer who must voice my adolescent experience') and my second novel, The Heaven I Swallowed (Hennessy 2013), with a more circumspect view, but still confident of my ability to navigate the fraught territory of creating an indigenous character without primary access to indigeneity. In attempting the latter I did not, as Leane urges, immerse myself in Aboriginal culture, but rather drew on postcolonial theories to recognise the problematics of previous textual representations of indigeneity and, in effect, talk back to these in my fiction. Writing the novel within the academy I was able to closely consider, in the $\mathrm{PhD}$ exegesis, issues of responsibility. While I began the story within the realms of realism, I concluded that a 'more symbolic or allegorical narrative where anxiety is inherent and the problematics of indigenous and non-indigenous relations continue indefinitely' (Hennessy 2009: 67-68) was necessary. My non-indigenous narrator, a woman called Grace, became a 'social-historical symbol of white Australia in the second half of the twentieth century' (Leane 2015: 137) and I worked hard to give the indigenous character, a young girl called Mary, both presence and agency, a fact recognised by at least one reviewer (interestingly, Jeanine Leane herself):

through these snippets of Mary, Hennessy creates subtle clues that Mary has more agency than Grace or any of the other adults in the community think. This ... is a poignant and clever metaphor - a testimony to the resilience and determination of Aboriginal people. (Leane 2015: 138)

Here my work did not emerge from cultural immersion, but from textual immersion, and an imagined dialogical relationship between historical stereotypes, ripe for undermining.

The question I find myself asking is: would I attempt the same today? That is, have the parameters drawn around the boundaries of fiction by these questions of representation and voice become so much more complicated in the past decade (my novel and thesis were completed in 2009) that I no longer feel confident doing anything but excavating the self? And what to do if this self is positioned at the centre of the mainstream? I am not seeking to glorify a past when writers were free to appropriate anyone else's experience for the sake of their art. Nor to bemoan an inability to occupy and know what it is to be disadvantaged and the injustice of not being allowed to imagine that disadvantage. This was, ultimately, the trap Shriver fell into. What intrigues me 
are the intersections between: (1) the practicalities of being a responsible writer who creates fiction which does not, to any degree, engage in a form of appropriation, (2) the concurrent search for voice without the comfort of a stable, knowable $I$ and (3) the downgrading of the development of personal style as a viable aim for literary writing. Yet when I say 'intrigues' I wonder if this is the right word, for the more I try to work at these intersections the more the way forward becomes murky and I wish, like many of my students, to retreat to my known identity. In fact, I wonder if my third novel is the fictionalisation of a creative writing Master Class because this is relatively safe material, a simulacrum of this Author's known, lived experience? Ironically, perhaps then, my novel 'The Master Class' is primarily concerned with the question of appropriation. The ideas explored in the novel are about power and an examination of all writing as an act of thievery.

'You took my story, Jemima.'

'You shared it with me, Roseanna, and I took a version of it and made it mine.'

'I shared it with you as a friend, not as a writer.'

'But I am a writer.'

'No, you're a thief.'

'What's the difference? Isn't that what writers do? Steal a little bit here, embellish a little bit there? There's a marked difference between my character and your life experience.'

'A "marked difference”. Listen to you. You should be on a stage. And I guess you will be.'

'There's no point in getting narky with me.'

'Narky? You've taken my story!'

'Stop saying that.'

'You've taken it, Jemima. And what do I have without it? What am I without it?'

... We are all searching. Freud thought us writer types were like children, wanting to return to the act of playing, to the times when we were controllers of our own little worlds: the farm animals in the wooden pens; the fairies in the stone gardens; the pirates in their Lego boats, manipulated by our whims. Finding a way back to the time when we were a god. Though, if you ever watch a child, you'll see all they create are disasters: floods and earthquakes and crashes. Those who write aren't so theatrical. Not all of the time. Writing can be just another way to make sense of it, the 'it' being these strange days, this bumping into each other, the mystery of being inside one body and not another. 
Freud asserts, in 'Creative Writers and Day-Dreaming' (1908) that 'every child at play becomes like a creative writer, in that he recreates a world of his own, or rather, rearranges the things of his world in a new way which pleases him' (Freud 1995: 3-4). When Freud flips the analogy he makes the writer a child:

The creative writer does the same as the child at play. He creates a world of phantasy which he takes very seriously - that is, which he invests with large amounts of emotion... (Freud 1995: 4)

and suggests that

a piece of creative writing, like a day-dream, is a continuation of, and a substitute for, what was once the play of childhood.

This vision of the writer as a child-like, omnipotent controller of worlds produces a distancing effect, enabling student writers to spend many hours using 'their fantasies in the production of socially valued objects' (Hecq 2008). Perhaps, by sheer virtue of their position - their place in the academy which affords them time and space to explore their creativity - they will develop a voice, a style, which stems not only from their unique self but from their ongoing aesthetic decisions.

Kevin Brophy, in tracking the ideas of 'style' from Aristotle's Poetics through to contemporary writings by Annie Dillard and James Wood, comes to the conclusion:

Style ... is what will happen if we write enough for long enough while remaining open to the unexpected. Style will happen because we do make choices, and those choices will cohere as a recognisable style partly because they express a personality and its set of values, partly because, as we keep writing and keep receiving feedback we gain the experience that makes our choices more of a whole, and most importantly it will be a living aspect of our work. (Brophy 2008)

If we hold onto this belief that a way of writing will develop - by the sheer virtue of continuing to write - then we can reassure the student writer they can move forward, via drafting and feedback. The act of writing itself will produce the act of writing. Indeed, it is often the case that the emergent writer is seeking to get beyond the voices of doubt, to give themselves permission to write the rubbishy first draft, to stop comparing themselves to the 'greats' of literature and value their own production.

Yet Brophy's use of the terms 'personality', 'set of values' and 'choices' also highlights the ways in which the production of creative work is inevitably linked to a greater sense of the world, to an awareness of how aesthetic judgements do not exist in a void. Bringing the question of authority into the classroom intersects with notions of diversity and social inclusivity, "tracing ways in which "commonsense" knowledge and assumptions make it difficult to see oppression clearly' (Bell 2007: 1). By underscoring the value of 'discerning patterns, often invisible in daily life, that reflect systemic aspects of oppression' (Bell 2007: 1) we open up, not only the important question of who should write what story but also ask the question: who is the author in the first place? Where does their author-ity come from? Here, the student writer is challenged to consider their position within cultural, economic and gender systems or as Patrick Bizzaro puts it: 'teachers must spend less time telling our students what they should do when they write and more time showing them 
who they can be' (Bizzaro 1994: 234). This focus on position should not be equated with the post-human application of identity layers placed upon the middle-class, white, male, able-bodied, heterosexual subject. That is, I believe there is actually little point in encouraging students to become caught up in what has been derogatorily called, by Shriver and others, 'identity politics'. Such a trajectory can reinforce the notion that only known subject positions can be explored, which not only traps the mainstream writer, but also those who may not want to embody their marginalised position in their writing. Rather, a greater conception of the ways in which fiction inevitably connects with the political - whether intended or not - needs to be discussed early on in a writer's career, rather than later. Here I am using the definition of politics provided by Jacques Rancière, in Politics of Aesthetics:

Politics revolves around what is seen and what can be said about it, around who has the ability to see and the talent to speak, around the properties of spaces and the possibilities of time. (Rancière 2013: 8)

Instead of speaking in the language of privilege or guilt-ridden questions of access - where markers of class, race, gender, sexuality and able-ism are contested, in some bizarre trumping of lived experience - students can be encouraged to understand fiction not as a playground for their gated imaginations, but as a vital engagement with the world. In their introduction to Fictionalizing the World, Louisa Söllner and Anita Vrzina write:

It is difficult to imagine a way of accessing the world that is not defined by processes of mediation, translation, interpretation, and fictionalization... Once we accept the impact that fiction exerts on our understanding of the world, we also have to acknowledge the political dimension of fictionalization. What is at stake here is a new understanding of the immediacy of sensory experience and its relationship to - and indeed dependence on - a specific, socially constructed, normative system of thought. (Söllner \& Vrzina 2015: 8)

Or, more succinctly, Rancière writes: 'To pretend is not to put forth illusions but to elaborate intelligible structures' (2013: 32). The challenge remains as to how this awareness can be practically applied in the classroom around the questions of voice and point of view.

While many writers will concede their debt to reality in the creation of character or story, the idea of fiction writing as an act of political intent only seems to arise if there is some large, obvious transgression from one position of power to another, for example, in the case of writing an indigenous character as a non-indigenous writer. Yet the decision to write from a female point of view, as a male writer, or the creation of a character with Asperger's Syndrome from an abled writer, falls within the same arena of challenge, where the responsibility of the author is to the boundaries of the Othered. And, indeed, the decision to stay within the confines of the 'normative system of thought' (Söllner and Vrzina 2015: 8) is as political as to stray outside of it. Thus it does not become about setting up fences around the knowable or un-knowable subject but, instead, requires drawing attention to the political act of creating voice and the ways in which developing a distinct personal style may require racial, cultural, sexual or gendered immersion to enable a writer to 'get it right'. If a writer is someone who pays attention to the world, then the teacher can reposition fiction writing as political engagement, where there is a need to recognise and discuss the consequences of a representation that is not aware of the structures in which it is created. 
My authority, then, as a teacher stems not from my prior accomplishments my voice is not to be heard because I am an Author - but from my responsibility to raise questions as to how much the student writer needs to interact with their own author-ity to create a plausible voice; how they might traverse the boundaries of their knowledge respectfully; and to what extent their fictionalisation of the world reinforces or challenges dominant modes of representation.

'When we stumble upon a story - via a footnote, a whispered confession, a newspaper article - we do not need to ask "do I have the right?" This is a tedious and mundane question imposed on us by those who would police art and erect their barrier of identity politics. What we need to ask is "what will it make of me"? If we read to find ourselves, then the writer is the first excavator. It is he who does the initial dig and brings up the bodies. So what will it signify to the world I am capable of imagining and what will it mean to my soul if I create a character only to torment them and watch them die? Where will I end up if the places I inhabit are populated by voyeuristic misery? Who will I become? These are the important considerations, the essence of what it is to be an author.'

He stepped back, signalling his talk had come to an end. Applause sounded out, the acoustics of the room enabling it to seem a great deal stronger than it actually was.

\section{Works cited}

Abdel Magied, Y 2016 'As Lionel Shriver made light of identity, I had no choice but to walk out on her', The Guardian (10 September):

https://www.theguardian.com/commentisfree/2016/sep/10/as-lionel-shriver-made-light-ofidentity-i-had-no-choice-but-to-walk-out-on-her (accessed 30 November 2017) return to text

Barry, P 2009 Beginning Theory: An Introduction to Literary and Cultural Theory (3rd ed), Manchester University Press, Manchester return to text

Barthes, R 2001 [1968] 'The Death of the Author', in VB Leitch et al (eds) The Norton Anthology of Theory and Criticism WW Norton \& Company: 1466-1470 return to text

Bell, LA 2007 'Theoretical Foundations for Social Justice Education', in Adams et al (eds) Teaching for Diversity and Social Justice, Taylor \& Francis: 1-14 return to text

Bizzaro, P 1994 'Reading the Creative Writing Course: The Teacher's Many Selves', in W Bishop \& H Ostrom (eds) Colors of a Different Horse: Rethinking Creative Writing Theory and Pedagogy, National Council of Teachers of English, Urbana IL: 234-247 return to text

Brophy, K 2008 'The Poetics of Style: Staying Alive', TEXT 12, 2 (October): http://www.textjournal.com.au/oct08/brophy.htm (accessed 29 November 2017) return to text

Cowan, A 2012 'A live event, a life event: The workshop that works', TEXT 16, 1 (April): http://www.textjournal.com.au/april12/cowan.htm (accessed 01 August 2018) return to text

Dawson, P 2007 'The Future of Creative Writing', in S Earnshaw (ed) The Handbook of Creative Writing Edinburgh University Press, Edinburgh: 78-90 return to text

Deakin University 2018 'The Stories We Tell: Inventing Selves and Others (ALL101)', Deakin University Unit Information: http://www.deakin.edu.au/courses/unit?unit=ALL101 (accessed 11 September 2018) return to text 
Fraser, G 2008 'A Translator's Tale', in G Harper \& J Kroll (eds) Creative Writing Studies: Practice, Research and Pedagogy, Multilingual Matters, Clevedon Somerset: 152-164 return to text

Freud, S 1995 [1908] 'Creative Writers and Day-Dreaming', in E Spector Person et al (eds) On Freud's 'Creative Writers and Day-dreaming', Yale University Press, New Haven \& London: 1-14. Available at: https://www.jstor.org/stable/j.ctt2250vrw (accessed 9 October 2018) return to text

Gandolfo, E 2016 'We need to talk about identity politics...', TEXT 20, 2 (October): http://www.textjournal.com.au/oct16/editorial.htm (accessed 29 November 2017) return to text

Hecq, D 2008 'Writing the unconscious: psychoanalysis for the creative writer', TEXT 12, 2 (October): http://www.textjournal.com.au/oct08/hecq.htm (accessed 29 November 2017) return to text

Harris, M 2009 'Escaping the tractor beam of literary theory: notes towards appropriate theories of creative writing - and some arguments against the inappropriate ones', TEXT 13, 2 (October): http://www.textjournal.com.au/oct09/harris.htm (accessed 7 September 2018) return to text

Hennessy, R 2009 Whose Shoes? Writing The Heaven I Swallowed, Unpublished PhD thesis, School of English \& Creative Writing, University of Adelaide, Adelaide return to text

Hennessy, R 2013 The Heaven I Swallowed, Wakefield Press, Kent Town SA return to text Jameson, F 2001 [1988] 'Postmodernism and Consumer Society', in VB Leitch et al (eds) The Norton Anthology of Theory and Criticism WW Norton \& Company: 1960-1974 return to text

Leane, J 2015 'The Heaven I Swallowed', Australian Aboriginal Studies 1: 137-138 return to text

Leane, J 2016 'Other people's stories', Overland 225: 41-45 return to text

Merriam-Webster 2018 'Responsible' [Def 2a] Merriam-Webster Online: https://www.merriam-webster.com/dictionary/responsible (accessed 2 October 2018) return to text

Muecke, S 2002 'The Fall: Fictocritical Writing', Parallax 8, 4: 108-112 return to text

Quilford, R 2016 'Conversations with Althusser, Bakhtin and Genette: The influence of theory on creative practice', TEXT 20, 2 (October): http://www.textjournal.com.au/oct16/quilford.htm (accessed 7 September 2018) return to text

Ramey, L 2014 'Creative Writing and Critical Theory', in S Earnshaw (ed) The Handbook of Creative Writing, Edinburgh University Press, Edinburgh: $42-53$ return to text

Rancière, J 2013 [2004] Politics of Aesthetics, Bloomsbury, London return to text

Shriver, L 2016a 'Will the Left Survive the Millennials?', The New York Times (23 September): https://www.nytimes.com/2016/09/23/opinion/will-the-left-survive-the-millennials.html (accessed 29 November 2017) return to text

Shriver, L 2016b 'Lionel Shriver's full speech: "I hope the concept of cultural appropriation is a passing fad", The Guardian (13 September):

https:/www.theguardian.com/commentisfree/2016/sep/13/lionel-shrivers-full-speech-i-hopethe-concept-of-cultural-appropriation-is-a-passing-fad (accessed 29 November 2017) return to text

Söllner, L \& A Vrzina (eds) 2015 Fictionalizing the World: Rethinking the Politics of Literature, Peter Lang, Frankfurt am Main return to text

Smith, H 2014 'Creative-Critical Hybrids', in S Earnshaw (ed) The Handbook of Creative Writing, Edinburgh University Press, Edinburgh: 331-340 return to text

Sved, M 2005 'Fractured Writing: Creativity, the University and the Australian Culture Wars', TEXT 9, 2 (October): http://www.textjournal.com.au/oct05/sved.htm (accessed 7 September 2018) return to text 
Tompkins, J 2001 [1987, 1989] 'Me and My Shadow', in VB Leitch et al (eds) The Norton Anthology of Theory and Criticism, WW Norton \& Company: 2129-2143 return to text

University of Melbourne 2018 'Creative Writing: Ideas and Practice (CWRI10001)', University of Melbourne Handbook:https://handbook.unimelb.edu.au/subjects/cwri10001/ (accessed 11 September 2018) return to text

Vanderslice, S 2011 Rethinking Creative Writing in Higher Education: Programs and Practices That Work, The Professional and Higher Partnership, Wicken Cambs return to text

Wandor, M 2004 'Creative Writing and Pedagogy 1: Self Expression? Whose Self and What Expression?', New Writing: The International Journal for the Practice and Theory of Creative Writing 1, 2: 112-123 return to text

Watkins, R \& N Krauth 2016 'Radicalising the scholarly paper: New forms for the traditional journal article', TEXT 20, 1 (April):

http://www.textjournal.com.au/april16/watkins\&krauth.htm (accessed 19 November 2017) return to text

Dr Rachel Hennessy's second novel The Heaven I Swallowed (Wakefield Press, 2013) was completed as part of her PhD at the University of Adelaide. It was Runner up in The Australian/Vogel Award and long-listed for the Nita B Kibble Award. She teaches in the School of Culture and Communication at the University of Melbourne.

\section{TEXT}

Vol 22 No 2 October 2018

http://www.textjournal.com.au

General Editor: Nigel Krauth. Editors: Julienne van Loon \& Ross

Watkins

text@textjournal.com.au 